\title{
Influence of the genetic structure of the red and blue shrimp, Aristeus antennatus (Risso, 1816), on the sustainability of a deep-sea population along a depth gradient in the western Mediterranean
}

\author{
FRANCISCO SARDÀ ${ }^{1}$, MARÍA INÉS ROLDÁN ${ }^{2}$, SANDRA HERAS $^{2}$ \\ and FERRUCCIO MALTAGLIATI ${ }^{3}$
}

${ }^{1}$ Institut de Ciències del Mar de Barcelona (CSIC), Passeig Marítim 37-49, 08003 Barcelona, Spain.

${ }^{2}$ Laboratori d’Ictiologia Genètica, Universitat de Girona, 17071 Girona, Spain. E-mail: marina.roldan@udg.edu

${ }^{3}$ Dipartimento di Biologia, Università di Pisa, Via Derna 1, 56126 Pisa, Italy.

SUMMARY: The red and blue shrimp, Aristeus antennatus, inhabits deep shelf waters in the Mediterranean Sea, where the shallower portion of its distribution supports a large commercial fishery. Recent prospecting surveys in the western Mediterranean have detected virgin stocks dwelling at more than $1000 \mathrm{~m}$, but the extent of gene flow between the exploited shallowdwelling stock and the deep-dwelling stock is unknown. To investigate the genetic structure of the population and estimate the depth component of gene flow, a portion of the mitochondrial DNA $16 S$ gene $(547 \mathrm{pb})$ was sequenced for 321 individuals from four different depths $(350,700,1100$ and $1500 \mathrm{~m})$ at a location in the Catalan Sea. Haplotype and nucleotide diversity values were low and did not significantly differ across depths. Analysis of molecular variance showed no significant genetic differences between depths. Mismatch distribution and neutrality tests indicated that A. antennatus has undergone recent demographic expansion in the two shallowest layers. Our results suggest that the species is genetically structured as a sort of metapopulation in which gene flow that occurs during the larval and juvenile stages, when larvae are carried downstream and juveniles are carried upstream by cascading, plays an important role in the resilience of the exploited layers.

Keywords: red and blue shrimp, Aristeus antennatus, mtDNA, 16S rDNA, gene flow, depth distribution, Western Mediterranean, metapopulation.

RESUMEN: INFLUENCIA DE LA ESTRUCTURA GENÉtica DE LA GAMBA ROSADA, ARISTEUS ANTENNATUS (Risso, I8I6) EN LA SOSTENIBILIDAD DE SU POBLACIÓN A TRAVÉS DEL GRADIENTE DE PROFUNDIDAD EN EL MEDITERRÁNEO OCCIDENTAL. - La gamba rosada Aristeus antennatus habita las aguas profundas del Mar Mediterráneo, donde los stocks de aguas más someras soportan una importante presión pesquera. Recientes campañas de prospección llevadas a cabo en el Mediterráneo Occidental han detectado stocks vírgenes a más de $1000 \mathrm{~m}$ de profundidad, pero se desconoce el flujo génico entre estos stocks y los menos profundos. Con el fin de investigar la estructura genética de dichos stocks, y estimar el componente de flujo génico entre ellos, se secuenció una porción de ADN mitocondrial, el gen $16 \mathrm{~S}$ (547 bp) en 321 individuos procedentes de cuatro profundidades $(350,700,1100$ y 1500 m) de una localidad del mar Catalán. Los valores de diversidad haplotípica y nucleotídica fueron bajos y no resultaron significativos entre profundidades. El análisis de la varianza molecular tampoco mostró diferencias significativas entre profundidades. La distribución mismatch y los tests de neutralidad indicaron que A. antennatus tuvo una expansión demográfica reciente en las dos fracciones menos profundas. Nuestros resultados sugieren que la gamba rosada está genéticamente estructurada como una metapoblación donde el flujo génico ocurre, en parte, mediante la deriva de larvas y de juveniles, cuando éstos últimos aparecen en las zonas menos profundas en los períodos siguientes al cascading. Este aspecto juega un rol importante en la capacidad de recuperación de los stocks explotados.

Palabras clave: gamba rosada, Aristeus antannatus, ADN mitocondrial, 16S rADN, flujo génico, distribución profunda, Mediterráneo Occidental, metapoblación. 


\section{INTRODUCTION}

The red and blue shrimp, Aristeus antennatus (Risso, 1816), is a major resource for Mediterranean Sea fisheries (Sardà and Demestre, 1987; Carbonell et al., 1999; D'Onghia et al., 2005). This species makes up only $15 \%$ of demersal landings in terms of biomass, but can account for over $50 \%$ of the value of the total landings from the coastal waters off Catalonia (Company et al., 2008). The A. antennatus fishery off Catalonia (western Mediterranean) follows the species' spatial and temporal movements through the submarine canyons and on the open middle slope at depths of between 600 and 900 m (Sardà et al., 1994; Sardà et al., 1997; Tudela et al., 2003). In addition, this species has been recorded down to depths of nearly $3000 \mathrm{~m}$, which makes it the most eurybathic species in the Mediterranean (Sardà et al., 2004). How it adapts to different depths and energy availability levels is so far unknown (Company et al., 2008), but its demographic structure is known to change with depth (Sardà et al., 2004). In fact, red and blue shrimp abundance and biomass decrease below $1000 \mathrm{~m}$, where there is a concomitant reduction in the proportion of females. This means that reproduction takes place mainly on the middle slope in late spring and summer (Orsi Relini and Relini, 1979; Sardà and Demestre, 1987; Carbonell et al., 1999; Papaconstantinou and Kapiris, 2001), when ripe females concentrate at around 700-800 m, with little spawning taking place in deeper waters. Moreover, early juveniles dwell at around $1200 \mathrm{~m}$ (Sardà and Cartes, 1997); below this depth, $A$. antennatus abundance drops off sharply, but some individuals have nonetheless still been recorded down to $2880 \mathrm{~m}$ in the western Mediterranean (Sardà et al., 2004).

The different demographic patterns observed between the deepest habitats and the middle-slope grounds are suggestive of separate subpopulations, usually defined as self-sustaining subunits of a species, with some adapted to the more oligotrophic and stable deep-sea environment. Recently, Company et al. (2008) suggested that hydrographic events that occur during particularly dry, windy, and cold winters in the Northwest Mediterranean give rise to cascading of dense water masses from the shelf to depths $>2000 \mathrm{~m}$. These events supposedly displace a large portion of the A. antennatus stocks from the fishing grounds to deeper waters, causing a decline in this species' fishery in the following 2-5 years. Migration of juveniles from areas below $1000 \mathrm{~m}$ leads to the recovery of A. antennatus stocks in the fishing grounds (Company et al., 2008).

Sardà et al. (1998) performed allozyme and morphometric analyses on the Mediterranean red and blue shrimp to assess possible differences between widely distributed fishing stocks in the Mediterranean Sea. They concluded that morphological differences among Mediterranean stocks of A. antennatus had no genetic basis but were a consequence of adaptive ecophenotypic plasticity in response to different habitats and oceanographic conditions in the Mediterranean and adjacent Atlantic Ocean waters.

This study addressed the vertical genetic structure of Aristeus antennatus by analysis of partial mitochondrial $16 S$ sequences in samples from four depths collected at one location in the Catalan Sea. In particular, the aim of the present study was to provide insight into connectivity in terms of gene flow between middle and lower slope and bathyal red and blue shrimp stocks. Mitochondrial DNA has been widely used to study genetic variability in marine organisms, including crustaceans (Avise, 2000). The DNA $16 S$ gene has previously been used by various researchers and has yielded good results in identifying crustacean populations (Avise, 2000; Roldán et al., 2009).

Since Mediterranean deep-sea resources are also considered highly vulnerable to anthropogenic impacts (Cartes et al., 2004), the findings presented here could hold out special interest for purposes of identifying the deepest-dwelling subpopulations as reservoir stocks and defining their role in the resilience of exploited grounds. Detailed information on red and blue shrimp population structure and genetic diversity is needed in order to formulate effective management measures for the fishery.

\section{MATERIALS AND METHODS}

Samples of Aristeus antennatus were collected by deep-sea trawling off Barcelona on two surveys (R/V García del Cid) carried out in November 2003 (103 individuals) and May 2004 (218 individuals) (Table 1). White muscle tissue was excised from the last abdominal segment of each individual and stored in 95\% ethanol. Genomic DNA extraction and $16 \mathrm{~S}$ mitochondrial gene amplification and sequencing were performed according to the procedures outlined in Roldán et al. (2009). We used the polymerase chain reaction (PCR) primers detailed in Roldán et al. (2009). Standard precautions, including the use of negative controls, were taken to assess contamination and related problems. Amplified fragments were checked on 1\% agarose gel with ethidium bromide $(0.5 \mathrm{mg} / \mathrm{ml})$ and purified using a GFX PCR DNA and Gel Band Purification Kit (Amersham, Little Chalfont, Buckinghamshire, UK). DNA direct cycle sequencing reactions were performed with dye terminators (BigDye v1.1, Applied Biosystems, Foster City, CA, USA) according to the manufacturer's instructions. Sequencing primers were the same as for PCR. Finally, labelled sequences were loaded onto an ABI PRISM 3130 Genetic Analyzer (Applied Biosystems) at the University of Girona laboratory.

The nucleotide sequences were aligned and edited using SeqScape ver. 2.5 (Applied Biosystems). Final alignments were carried out using BioEdit ver. 7.0.4.1 (Hall, 1999) taking as reference the $16 S$ rRNA sequence of Penaeus monodon (GenBank accession no. AF217843). Haplotype sequences were deposited in GenBank (accession numbers EU977139-EU977176). 
TABLE 1. - Aristeus antennatus. Haplotype frequencies at the four sampling depths in the Catalan Sea off Barcelona with GenBank accession numbers for each haplotype.

\begin{tabular}{|c|c|c|c|c|c|c|}
\hline Haplotype & Frequency & $\begin{array}{l}350 \mathrm{~m} \\
N=45\end{array}$ & $\begin{array}{c}700 \mathrm{~m} \\
N=206\end{array}$ & $\begin{array}{l}1100 \mathrm{~m} \\
N=46\end{array}$ & $\begin{array}{l}1500 \mathrm{~m} \\
N=24\end{array}$ & GenBank \\
\hline Aal & 0.809 & 38 & 164 & 37 & 20 & EU977139 \\
\hline $\mathrm{Aa} 2$ & 0.071 & 2 & 14 & 5 & 1 & EU977140 \\
\hline $\mathrm{Aa} 3$ & 0.006 & & 1 & & 1 & EU977141 \\
\hline $\mathrm{Aa} 4$ & 0.006 & & 1 & 1 & & EU977142 \\
\hline Aa5 & 0.003 & 1 & & & & EU977143 \\
\hline Aa6 & 0.003 & 1 & & & & EU977144 \\
\hline Aa7 & 0.003 & 1 & & & & EU977145 \\
\hline Aa8 & 0.003 & 1 & & & & EU977146 \\
\hline Aa9 & 0.003 & 1 & & & & EU977147 \\
\hline Aa10 & 0.006 & & 2 & & & EU977148 \\
\hline Aa11 & 0.006 & & 2 & & & EU977149 \\
\hline Aa12 & 0.003 & & 1 & & & EU977150 \\
\hline Aa13 & 0.003 & & 1 & & & EU977151 \\
\hline Aa14 & 0.003 & & 1 & & & EU977152 \\
\hline Aa15 & 0.003 & & 1 & & & EU977153 \\
\hline Aa16 & 0.003 & & 1 & & & EU977154 \\
\hline Aa17 & 0.003 & & 1 & & & EU977155 \\
\hline Aa18 & 0.003 & & 1 & & & EU977156 \\
\hline Aa19 & 0.003 & & 1 & & & EU977157 \\
\hline Aa20 & 0.003 & & 1 & & & EU977158 \\
\hline Aa21 & 0.003 & & 1 & & & EU977159 \\
\hline Aa22 & 0.003 & & 1 & & & EU977160 \\
\hline Aa23 & 0.003 & & 1 & & & EU977161 \\
\hline Aa24 & 0.003 & & 1 & & & EU977162 \\
\hline Aa25 & 0.003 & & 1 & & & EU977163 \\
\hline Aa26 & 0.003 & & 1 & & & EU977164 \\
\hline Aa27 & 0.003 & & 1 & & & EU977165 \\
\hline Aa28 & 0.003 & & 1 & & & EU977166 \\
\hline Aa29 & 0.003 & & 1 & & & EU977167 \\
\hline Aa30 & 0.003 & & 1 & & & EU977168 \\
\hline Aa31 & 0.003 & & 1 & & & EU977169 \\
\hline Aa32 & 0.003 & & 1 & & & EU977170 \\
\hline Aa33 & 0.003 & & 1 & & & EU977171 \\
\hline Aa34 & 0.003 & & & 1 & & EU977172 \\
\hline Aa35 & 0.003 & & & 1 & & EU977173 \\
\hline Aa36 & 0.003 & & & 1 & & EU977174 \\
\hline Aa37 & 0.003 & & & & 1 & EU977175 \\
\hline $\mathrm{Aa} 38$ & 0.003 & & & & 1 & EU977176 \\
\hline
\end{tabular}

A hierarchical series of tests based on the Bayesian Information Criterion was applied to identify the most appropriate nucleotide substitution model among 56 models tested, as implemented in MODELTEST 3.7 (Posada and Crandall, 1998). Haplotype diversity $(h)$ and nucleotide diversity $(\pi)$ were calculated using DnaSP ver. 4.10 .9 (Rozas et al., 2003) and ARLEQUIN ver. 3.01 (Excoffier et al., 2005). Hierarchical analysis of molecular variance [AMOVA, Excoffier $e t$ al. (1992)] was applied to all haplotypes to partition genetic variance into the within-depth and among-depth components. The significance of variance components and $\Phi$-statistic values was assessed by a permutation test with 10000 replicates. The BAPS (Bayesian Analysis of Population Structure) program ver. 4.14 (Corander et al., 2003; Corander and Marttinen, 2006) was employed to detect hidden population substructure by clustering sampled individuals into panmictic groups. BAPS adopts a Bayesian approach with a stochastic optimization algorithm for analyzing models of population structure, which greatly improves the speed of the analysis compared with traditional MCMC-based algorithms (Corander and Marttinen, 2006). The only prior information given was the site of origin of each individual. When testing for population clusters, we ran five replicates for every value of $k$ ( $k$ is the maximum number of clusters) up to $k=8$. In addition, we used a number of reference individuals $=$ 500 and repeated the admixture analysis 500 times per individual.

A haplotype network was constructed using NETWORK ver. 4.2.0.1 (Bandelt et al., 1999). Demographic history was inferred by analyzing the distribution of the number of site differences between pairs of sequences (mismatch distribution), which was carried out on the entire dataset according to the procedure outlined in Rogers and Harpending (1992) as implemented in DnaSP (Rozas et al., 2003). Expected values for a model of constant population size were calculated and plotted against the observed values. Populations that have experienced rapid demographic growth in the recent past exhibit unimodal distributions, while populations at demographic equilibrium have multimodal distributions (Rogers and Harpending, 1992). Theoretical distributions under models of assumed constant population size and sudden expansion were compared with the observed data. In the former model the population is expected to be stable over time, whereas in the 
latter model the original population that was at equilibrium $\left(\theta_{0}\right) \tau$ generations ago suddenly expands to a new size $\theta_{1}$. The sum of squared deviations between the observed and the expected mismatch distributions was used as the test statistic. Demographic parameters $\theta_{0}$ and $\tau$ were calculated with DnaSP, taking $\theta_{1}$ as infinite (Rogers, 1995). Fu's $F_{S}$ statistic (Fu, 1997) and Ramos-Onsins and Rozas's $R_{2}$ statistic (Ramos-Onsins and Rozas, 2002) were also computed to test for population expansion using DnaSP (Rozas et al., 2003). Statistical tests and confidence intervals were based on parametric bootstrapping with coalescence simulations.

\section{RESULTS}

A partial region (547 bp) of the mtDNA $16 \mathrm{~S}$ gene from 321 individuals collected at four depths in the Catalan Sea off Barcelona was analyzed. Thirty-seven polymorphic nucleotide sites were detected, eight of which were phylogenetically informative. All differences between haplotypes were substitutions. The outcome of MODELTEST showed that the appropriate model of nucleotide substitution for the $16 S$ DNA sequences of Aristeus antennatus was the HKY model of evolution (Hasegawa et al., 1985) with rate heterogeneity $(G)$. The proportion of invariable sites was zero. The base frequencies were $f_{\mathrm{A}}=0.290, f_{\mathrm{C}}=0.154, f_{\mathrm{G}}=$ $0.223, f_{\mathrm{T}}=0.333$.

Overall, 38 haplotypes were recorded, including 1 common haplotype (total frequency: $f=0.809$ ), 1 less common haplotype $(f=0.071), 4$ rare haplotypes $(f=$ $0.006)$, and 32 unique haplotypes $(f=0.003)$ (Table 1$)$. Only 2, also the most common haplotypes $(5 \%)$ of the 38 observed haplotypes, were present in samples from all the depths considered. Another 2 haplotypes (5\%) were shared by samples from two different depths, while the bulk of the haplotypes were depth-privates, with 5 (13\%) haplotypes private to the $350 \mathrm{~m}$ sample,

TABle 2. - Aristeus antennatus. Genetic diversity estimates in samples from different depths $(N$ : sample size; Nh: number of haplotypes; Np: number of polymorphic sites; $h$ : haplotype diversity; $\pi$ : nucleotide diversity).

\begin{tabular}{lccccc}
\hline Depth & $N$ & Nh & Np & $h$ & $\pi$ \\
\hline $350 \mathrm{~m}$ & 45 & 7 & 8 & $0.289 \pm 0.088$ & $0.0007 \pm 0.0003$ \\
$700 \mathrm{~m}$ & 206 & 28 & 26 & $0.363 \pm 0.043$ & $0.0009 \pm 0.0001$ \\
$1100 \mathrm{~m}$ & 46 & 6 & 5 & $0.347 \pm 0.086$ & $0.0007 \pm 0.0002$ \\
$1500 \mathrm{~m}$ & 24 & 5 & 4 & $0.312 \pm 0.121$ & $0.0008 \pm 0.0003$ \\
Total & 321 & 38 & 37 & $0.345 \pm 0.034$ & $0.0008 \pm 0.0001$ \\
\hline
\end{tabular}

TABLE 3. - Aristeus antennatus. Results of hierarchical analysis of molecular variance (AMOVA). $P$-values were calculated by a random permutation test with 10000 replications; the $\Phi$-statistic represents the likelihood of obtaining greater variance than the observed value by chance alone.

\begin{tabular}{|c|c|c|c|c|c|}
\hline $\begin{array}{l}\text { Source of } \\
\text { variation }\end{array}$ & df & $\begin{array}{c}\text { Variance } \\
\text { component }\end{array}$ & $\begin{array}{c}\text { Percentage } \\
\text { variance }\end{array}$ & $\Phi$-statistics & $P$ \\
\hline $\begin{array}{l}\text { Among depths } \\
\text { Within depth }\end{array}$ & $\begin{array}{c}3 \\
317\end{array}$ & $\begin{array}{c}-0.00099 \\
0.22605\end{array}$ & $\begin{array}{c}0 \\
100\end{array}$ & $\Phi_{\mathrm{ST}}=-0.004$ & 0.787 \\
\hline
\end{tabular}

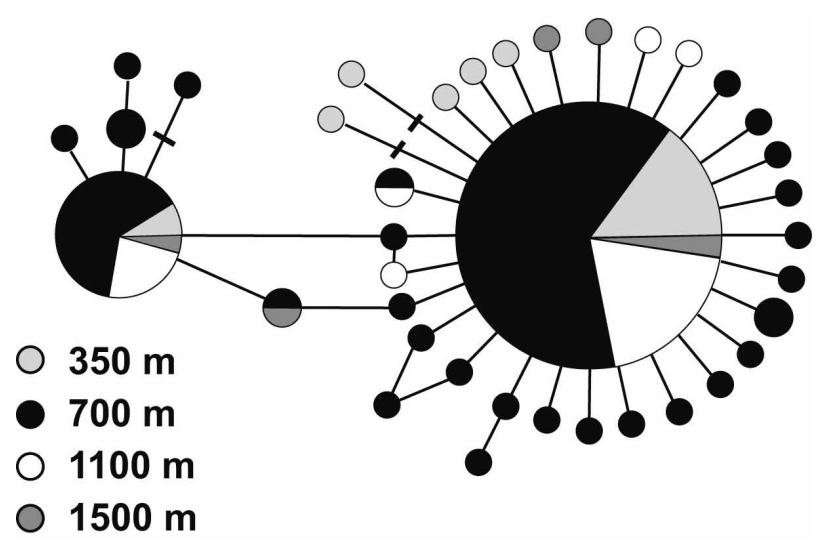

FIG. 1. - Aristeus antennatus. Median-joining haplotype network based on the mtDNA $16 \mathrm{~S}$ sequences recorded at the four sampling depths. The area of each circle is proportional to the number of individuals exhibiting that haplotype. Each line in the network represents one mutational step, and the bars represent missing or undetected haplotypes.

$24(64 \%)$ to the $700 \mathrm{~m}$ sample, $3(8 \%)$ to the $1100 \mathrm{~m}$ sample, and $2(5 \%)$ to the $1500 \mathrm{~m}$ sample (Table 1$)$. The mean values of haplotype and nucleotide diversity values were $h=0.345 \pm 0.034$ and $\pi=0.0008 \pm 0.0001$ (Table 2). Single-sample haplotype and nucleotide diversity values did not differ significantly according to a $t$-test on the arcsine square root transformed data (all $P$-values $>0.05)$. The AMOVA analysis distributed all the molecular variance in the within-depth components, and the fixation index $\left(\Phi_{\mathrm{ST}}\right)$ was not significantly different from zero (Table 3). The median-joining-network of haplotypes clearly displayed a star phylogeny, with the most frequent haplotype being shared by individuals from all depths and a number of derived unique or rare haplotypes connected, with very few exceptions, by only one mutation (Fig. 1). Replicate runs of BAPS yielded identical results and produced three genetic clusters $(P=0.563)$ (Fig. 2$)$; however, the probability value associated with the two-cluster scenario was not substantially lower $(P=0.437)$. Ten further replicates for each of the two- and three-cluster scenarios produced very similar log maximum likelihood average values $(-471.953 \pm 0.895$ and $-471.942 \pm 0.703$, respectively.) The proportions of the three genetic clusters did not differ substantially across the samples from the four different depths (Fig. 2). The mismatch distribution results within the samples from each depth as well as in the data set overall were consistent with past population growth (data not shown), though the other tests yielded slightly contrasting outcomes (Table 4). Neutrality tests were significant for the data set as a whole, and all the statistics tests were significant for the 700-m sample (Table 4). Ramos-Onsins and Rozas (2002) found $F_{\mathrm{S}}$ to be the most powerful statistic for large sample sizes and $R_{2}$ for small sample sizes. On this basis, our results suggest population expansion only at the two shallowest depths sampled. Accurate dating of this expansion was not possible, since the mutation rate for the $16 \mathrm{~S}$ region has not been estimated for this species. 
$350 \mathrm{~m}$

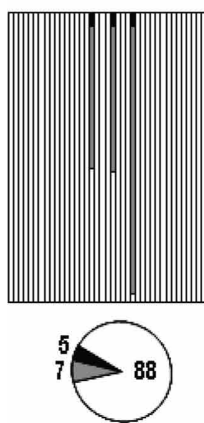

$700 \mathrm{~m}$

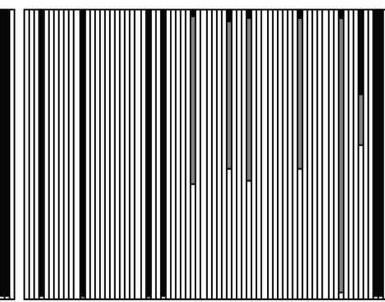

$1100 \mathrm{~m}$
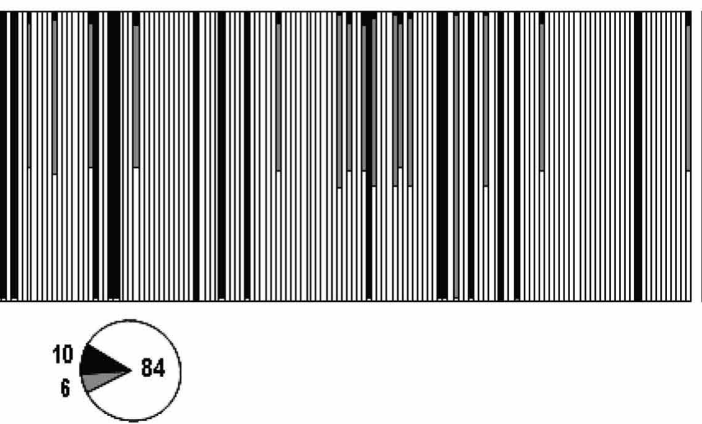

$1500 \mathrm{~m}$

FIG. 2. - Aristeus antennatus. Results of Bayesian assignment analysis. Three genetic clusters (black, grey, and white) were identified $(P=0.563)$, the colours representing the assignment probabilities of individual genotypes to a cluster. In the bar graphs each bar represents an individual, whereas overall proportions of the three genetic clusters in the depth samples are represented by pie charts.

TABLE 4. - Aristeus antennatus. Neutrality tests for the four depth samples $\left[\theta_{0}\right.$ was calculated taking $\theta_{1}$ as infinite (see Rogers, 1995)].

\begin{tabular}{lccccc}
\hline Depth & $\tau$ & $\theta_{0}$ & SSD & $\begin{array}{c}\text { Fu's } \\
F_{\mathrm{S}} \text { test }\end{array}$ & $\begin{array}{c}\text { Ramos-Onsins } \\
\text { and } \\
\text { Rozas's } R_{2} \text { test }\end{array}$ \\
\hline $350 \mathrm{~m}$ & 0.104 & 0.294 & $0.065^{\mathrm{ns}}$ & $-2.805^{*}$ & $0.059^{\mathrm{ns}}$ \\
$700 \mathrm{~m}$ & 0.217 & 0.269 & $0.079^{\mathrm{ns}}$ & $-29.223^{* * *}$ & $0.013^{*}$ \\
$1100 \mathrm{~m}$ & 0.372 & 0.000 & $0.080^{\mathrm{ns}}$ & $-2.113^{\mathrm{ns}}$ & $0.060^{\mathrm{ns}}$ \\
$1500 \mathrm{~m}$ & 0.199 & 0.210 & $0.075^{\mathrm{ns}}$ & $-1.303^{\mathrm{ns}}$ & $0.085^{\mathrm{ns}}$ \\
Total & 0.218 & 0.234 & $0.075^{\mathrm{ns}}$ & $-8.861^{*}$ & $0.009^{*}$ \\
\hline
\end{tabular}

ns non-significant, $* P<0.05, * * P<0.01, * * * P<0.001$

\section{DISCUSSION}

The estimates of genetic variability found in the present work were consistent with those found in a previous study of three geographical samples (Roldán et al., 2009). In that paper the same portion of $16 \mathrm{~S} \mathrm{mi-}$ tochondrial gene herein analyzed was treated jointly to a region of COI. Given that data of that work were at our disposal, we obtained estimates of genetic variability only for $16 S$ gene in the Catalan Sea sample (Palamós) for comparative purposes. In that sample we observed a substantially lower number of haplotypes and number of polymorphic sites $(\mathrm{Nh}=10$ and $\mathrm{Np}=$ 10 , respectively) due to the lower sample size $(N=60)$; however, the haplotype and nucleotide diversities $(h=$ $0.359 \pm 0.006$ and $\pi=0.0008 \pm 0.0002$ ) were virtually identical to those herein detected (cf. Table 2). Furthermore, haplotype diversity values calculated in the present work and those in Roldán et al. (2009) were substantially lower than values obtained by Maggio et al. (2009) in eight Mediterranean samples of Aristeus antennatus ( $h=0.884$ to 0.989 ) analyzed by means of sequencing of a $369 \mathrm{bp}$ portion of the mitochondrial control region, the maximum value being obtained for the Catalan Sea sample $(N=14)$. This difference accounts for the well-known higher mutation rate of the control region in comparison with the $16 \mathrm{~S}$ gene.

Genetic diversity estimated by haplotype and nucleotide diversity was generally low (Table 2). A recent prolonged or severe demographic bottleneck or a selective sweep may account for the low levels of genetic diversity observed (Grant and Bowen, 1998; Avise, 2000). Given that there are no data on the origin of Mediterranean red and blue shrimp populations, we cannot advance a sound explanation based on recent colonization. The observed low levels of diversity must be explained by other mechanisms, such as periodic regionwide bottlenecks (sweepstakes reproductive events) or metapopulation structure within regions.

The high levels of genetic homogeneity detected among the vertical samples of $A$. antennatus from the Catalan Sea were a reason for rejecting the hypothesis that the deeper-dwelling stocks are isolated from the exploited stocks previously proposed by Sardà et al. (2003). Furthermore, combining our results with those reported in Roldán et al., (2009), a general picture of relative genetic homogeneity emerges in the three spatial dimensions of the species distribution in the western Mediterranean. Larval and adult dispersal is, thus, effective at ensuring gene flow, and as a result significant vertical and geographical genetic structuring were absent.

Generally speaking, little work on decapod crustaceans has viewed their population structure as a metapopulation (Fogarty and Botsford, 2006). From the metapopulation standpoint, a central feature of most decapod species is how stability, variability, and continuity fluctuate as a result of the existence of several individual populations and larval exchange among them. However, information on larval development and behaviour of Aristeus antennatus is lacking, making the prediction of larval contribution to gene flow virtually impossible. Furthermore, to our knowledge, there is no information on the metapopulation structure of other, similar species of deep-sea shrimps, apart from a brief discussion of metapopulation aspects relating to Pandalus borealis in the North Atlantic and North Sea by Fogarty and Botsford (2006). Like A. antennatus, this species forms dense aggregations that have spatiotemporally well-defined sex compositions and size structures and well-defined exploitation patterns. Bergström (2000) postulated that certain localized stocks of $P$. borealis arise from recruitment from large pools of larvae. Hydrodynamic factors during the early stages 
of larval development likewise play an essential role. Results of genetic studies by Drengstig and Fevolden (1997), Martínez et al. (1997) and Drengstig et al. (2000) on P. borealis populations were consistent with our results, i.e. they found no significant genetic differences between Atlantic and Barents Sea populations. Thus, our results on red and blue shrimp can be likened to the metapopulation concept coined by Levins (1969) to describe a population consisting of a network of local populations connected by different degrees of gene flow, a portion of which faces a substantial likelihood of extinction. Extinction of local stocks of A. antennatus appears unrealistic, and no clear subpopulation boundaries are evident. However, reductions in population size due to fishing pressure and physical disturbance have been documented (Relini and Orsi Relini, 1987; Relini, 2007; Company et al., 2008). Source-sink theory (Pulliam, 1988) would therefore seem to hold for A. antennatus, in which the more shallow-dwelling harvested stocks can be considered sinks, while the deeper-dwelling stocks are sources.

In this way, the cascading effect reported by Company et al. (2008) translates into dispersal of individuals from the more stable stock occurring in the deeper and less disturbed habitat into shallower grounds, where trawling exerts considerable stress. These individuals come from segments of the population that have higher post-larval and juvenile survival rates and are able to colonize the more coastal areas via the submarine canyons located on the slope (Tudela et al., 2003). Nevertheless, an important additive contribution by horizontal gene flow among geographical stocks of A. antennatus cannot be excluded, as observed in the western Mediterranean by Roldán et al. (2009).

Within this framework, we might think of $A$. antennatus as a sort of metapopulation, in which harvesting leads to a reduction in the size of the more shallow-dwelling stocks, but not extinction, because the deeper-dwelling stocks are the source of an effective 'rescue effect' (Brown and Kodrick-Brown, 1977) contributing to the recovery of empty habitat patches in the fishing grounds. The hydrologic characteristics of the western Mediterranean, with its cascading events, vast deep-sea regions below $1000 \mathrm{~m}$ in the vicinity of fishing grounds, and the influence of large submarine canyons, favour the metapopulation-like pattern reported here. This hypothesis needs to be tested in other areas of species' distribution range that have different hydrographic features to assess the contribution of the above-mentioned factors in moulding the species' genetic architecture.

From a fisheries perspective, our results highlighted the value of the recently instituted recommendation by the FAO General Fisheries Commission for the Mediterranean (Rec. GFCM/2005/1), by which the Members of the GFCM shall prohibit the use of towed dredges and trawl nets fisheries at depths beyond 1000 $m$ depth. This ban represents an appropriate measure to safeguard the deepest-dwelling stocks of Aristeus antennatus in order to ensure sustainable exploitation of this important resource.

\section{ACKNOWLEDGEMENTS}

Samples were obtained from the RECS (CY7FKSNS-CICYT) and DESEAS (EEC DG Fisheries Study contract no. 00/0039) projects. The authors wish to thank Dr. J.B. Company and Dr. G. Rotllant for the material provided during the sampling cruises and two anonymous reviewers for comments on the manuscript. Thanks also to Dr. C. Pla for encouraging this study. Financial support for this work was provided by grant no. CTM2006-00785 to MIR.

\section{REFERENCES}

Avise, J.C. - 2000. Phylogeography. The history and formation of species. Harvard University Press, Cambridge, Massachusetts.

Bandelt, H.J., P. Forster and A. Rohl. - 1999. Median-joining networks for inferring intraspecific phylogenies. Mol. Biol. Evol., 16: $37-48$.

Bergström, B.I. - 2000. The biology of Pandalus. Adv. Mar. Biol., 38: $55-245$.

Brown, J.H. and A. Kodrick-Brown. - 1977. Turnover rates in insular biogeography: Effect of immigration on extinction. Ecology, 58: $445-449$.

Carbonell, A., M. Carbonell, M. Demestre, A. Grau and S. Montserrat. - 1999. The red shrimp Aristeus antennatus (Risso, 1816) fishery and biology in the Balearic Islands, Western Mediterranean. Fish. Res., 44: 1-13.

Cartes, J.E., F. Maynou, F. Sardà, J.B. Company, D. Lloris and S. Tudela. - 2004. The Mediterranean deep-sea ecosystems: an overview of their diversity, structure, functioning and anthropogenic impacts. In: IUCN/WWF (eds.), The Mediterranean deep-sea ecosystems: an overview of their diversity, structure, functioning and anthropogenic impacts with a proposal for their conservation. Part I, pp. 9-38. IUCN, Málaga and WWF, Rome.

Company, J.B., P. Puig, F. Sardà, A. Palanques, M. Latasa and R. Scharek. - 2008. Climate influence on deep-sea populations. PLOS ONE., 3(1), e1431.

Corander, J. and P. Marttinen. - 2006. Bayesian identification of admixture events using multi-locus molecular markers. Mol. Ecol., 15: 2833-2843.

Corander, J., P. Waldmann and M.J. Sillanpä. - 2003. Bayesian analysis of genetic differentiation between populations. Genetics, 163: 367-374.

D’Onghia, G., F. Capezzuto, Ch. Mytilineou, P. Maiorano, K. Kapiris, R. Carlucci, L. Sion and A. Tursi. - 2005. Comparison of the population structure and dynamics of Aristeus antennatus (Risso, 1816) between exploited and unexploited areas in the Mediterranean Sea. Fish. Res., 76: 22-38.

Drengstig, A. and S.E. Fevolden. - 1997. Genetic structuring of Pandalus borealis in the North Atlantic. 1. Allozyme studies. ICES CM. 1997/AA, 3.

Drengstig, A., S.E. Fevolden, P.E. Garland and M.M. Aschan. 2000. Genetic structure of the deep-sea shrimp (Pandalus borealis) in the north-east Atlantic based on allozyme variation. Aquat. Living Resour., 13: 121-128.

Excoffier, L., G. Laval and S. Schneider. - 2005. Arlequin ver. 3.0, An integrated software package for population genetics data analysis. Evolutionary Bioinformatics Online, 1: 47-50.

Excoffier, L., P.E. Smouse and J.M. Quattro. - 1992. Analysis of molecular variance inferred from metric distances among DNA haplotypes: application to human mitochondrial DNA restriction data. Genetics, 86: 991-1000.

Fogarty, M.J. and L.W. Botsford. - 2006. Metapopulation dynamics of marine decapods. In: J. Kritzer and P. Sale (eds.), Marine Metapopulations, pp. 271-319. Elsevier, London.

Fu, Y.X. - 1997. Statistical tests of neutrality of mutations against 
population growth, hitchhiking and background selection. Genetics, 147: 915-925.

General Fisheries Commission for the Mediterranean, 2005. ftp:// ftp.fao.org/FI/DOCUMENT/gfcm/web/GFCM_Recommendations2005.pdf

Grant, W.S. and B.W. Bowen. - 1998. Shallow population histories in deep evolutionary lineages of marine fishes: insights from sardines and anchovies and lessons for conservation. J. Heredity, 89: 415-426.

Hall, T.A. - 1999. BioEdit: a user-friendly biological sequence alignment editor and analysis program for Windows 95/98/NT Nucl. Acids Symp. Ser., 41: 95-98.

Hasegawa, M., K. Kishino and T. Yano. - 1985. Dating the humanape splitting by a molecular clock of mitochondrial DNA. $J$ Mol. Evol., 22: 160-174.

Levins, R. - 1969. Some demographic and genetic consequences of environmental heterogeneity for biological control. Bull. Entomol. Soc. Amer., 15: 237-240.

Maggio, T., S. Lo Brutto, R. Cannas, A.M. Deiana and M. Arculeo. -2009 . Environmental features of deep-sea habitats linked to the genetic population structure of a crustacean species in the Mediterranean Sea. Mar. Ecol., 30: 354-365.

Martínez, I., T. Skjerdal, B. Dreyer and S.M. Aljanabi. - 1997. Genetic structuring of Pandalus borealis in the north Atlantic. 2. RAPD analysis. ICES CM, 1997/T: 24.

Orsi Relini, L. and G. Relini. - 1979. Pesca e riproduzione del gambero rosso Aristeus antennatus (Decapoda, Penaeidae) nel Mar Ligure. Quad. Civ. Staz. Idrobiol. Milano, 7: 39-62,

Papaconstantinou, C. and K. Kapiris. - 2001. Distribution and population structure of the red shrimp (Aristeus antennatus) on an unexploited fishing ground in the Greek Ionian Sea. Aquat. Living Resour., 14: 303-312.

Posada, D. and K.A. Crandall. - 1998. Modeltest: testing the model of DNA substitution. Bioinformatics, 14: 817-818.

Pulliam, H.R. - 1988. Sources, sinks and population regulation. Am. Nat., 132: 652-661.

Ramos-Onsins, S.E. and J. Rozas. - 2002. Statistical properties of new neutrality tests against population growth. Mol. Biol. Evol., 19: 2092-2100.

Relini, G. - 2007. La pesca batiale in Liguria. Biol. Mar. Medit., 14: $190-244$

Relini, G. and L. Orsi Relini. - 1987. The decline of red shrimps stocks in the gulf of Genoa. Inv. Pesq., 51(Suppl. 1): 245-260.

Rogers, A.R, 1995. Genetic evidence for a Pleistocene population explosion. Evolution, 49: 608-615.
Rogers, A.R. and H. Harpending. - 1992. Population growth makes waves in the distribution of pairwise genetic differences. Mol. Biol. Evol., 9: 552-569.

Roldán, M.I., S. Heras, R. Patellani and F. Maltagliati. - 2009. Analysis of genetic structure in the red shrimp Aristeus antennatus from the Western Mediterranean, as revealed by two mitochondrial regions. Genetica, 136: 1-4.

Rozas, J., J.C. Sánchez del Barrio and X. Messegué. - 2003. DnaSP: DNA polymorphism analysis by the coalescent and other methods. Bioinformatics, 19: 2496-2497.

Sardà, F. and M. Demestre. - 1987. Estudio bioecológico de la gamba, Aristeus antennatus, Risso 1816, en el mar Catalán. Inv. Pesq. 51(Suppl. 1): 213-232.

Sardà, F. and J.E. Cartes. - 1997. Morphological features and ecological aspects of early juvenile specimens of the aristeid shrimp Aristeus antennatus (Risso, 1816). Mar. Freshwater Res., 48: 73-77.

Sardà, F., J.E. Cartes and W. Norbis. - 1994. Spatio-temporal structure of the deep-water shrimp Aristeus antennatus Risso, 1816 (Decapoda: Aristeidae) population in the Western Mediterranean. Fish. Bull., 92: 599-607.

Sardà, F., J.B. Company and F. Maynou. - 2003. Deep-sea shrimp Aristeus antennatus Risso 1816 in the Catalan sea, a review and perspectives. NAFO. J. Northwest Atl. Fish. Sci., 31: 127-136.

Sardà, F., F. Maynou and Ll. Talló. - 1997. Seasonal and spatial mobility patterns of rose shrimp (Aristeus antennatus Risso, 1816) in the western Mediterranean: results of a long-term study. Mar. Ecol. Progr. Ser., 159: 133-141.

Sardà , F., C. Bas, M.I. Roldán, C. Pla and J. Lleonart. - 1998. Enzymatic and morphometric analyses of the population structure of Aristeus antennatus (Risso, 1816) in its Mediterranean distribution area. J. Exp. Mar. Biol. Ecol., 221: 131-146.

Sardà, F., G. D'Onghia, C.Y. Politou, J.B. Company, P. Maiorano and K. Kapiris. - 2004. Deep-sea distribution, biological and ecological aspects of Aristeus antennatus (Risso, 1816) in the western and central Mediterranean Sea. Sci. Mar., 68(Suppl. 3): 117-127.

Tudela, S., F. Sardà, F. Maynou and M. Demestre. - 2003. Influence of submarine canyons on the distribution of the deep-water shrimp (Aristeus antennatus, Risso 1816) in the northwestern Mediterranean. Crustaceana, 76: 217-225.

Scient. ed.: E. Macpherson.

Received July 23, 2009. Accepted December 10, 2009.

Published online May 28, 2010. 